\title{
COMPARISON OF RAPID SEQUENCE INDUCTION INTUBATION CONDITIONS WITH SUXAMETHONIUM VERSES ROCURONIUM.
}

1. FCPS

Senior Registrar

Allied/DHQ Hospital, Faisalabad.

2. FCPS

Assistant Professor

Abwa Medical College, Faisalabad.

3. FCPS

Senior Registrar

Aziz Fatima Medical College,

Faisalabad.

4. MCPS, FCPS

Professor

Faisalabad Medical University,

Faisalabad.

5. FCPS

Assistant Professor

Aziz Fatima Medical College,

Faisalabad.

6. MCPS, FCPS

Senior Registrar

Abwa Medical College, Faisalabad.

Correspondence Address:

Dr. Ayesha Ahmad

Allied/DHQ Hospital, Faisalabad.

dr.saminau@hotmail.com

Article received on:

02/05/2019

Accepted for publication:

25/08/2019

\section{Aisha Ahmad 1 , Samina Aslam², Amna Tariq ${ }^{3}$, Robina Firdous ${ }^{4}$, Humaira Ahmad ${ }^{5}$, ljaz Ahmed}

ABSTRACT... Objectives: To compare endotracheal intubating conditions in rapid sequence induction using Suxamethonium and Rocuronium. Study Design: Randomized Controlled Trial. Setting: Allied Hospital Faisalabad. Period: From 02-07-2015 to 01-07-2016. Material \& Methods: After taking approval from hospital ethical committee, cases of emergency surgery fulfilling the inclusion criteria were enrolled and informed consent was taken after explaining all the procedure to the patient. All the patients were randomly divided into 2 groups by using computer generated random number table. Both groups were induced with thiopentone sodium $5 \mathrm{mg} / \mathrm{kg}$, analgesia was given with nalbuphine $0.1 \mathrm{mg} / \mathrm{kg}$. Group A was given Suxamethonium in a dose of $1 \mathrm{mg} / \mathrm{kg}$ body weight after induction agent. Group B was given $0.6 \mathrm{mg} / \mathrm{kg}$ Rocuronium after induction. Intubation was performed after $60 \mathrm{sec}$ in both groups with cricoid pressure. Anesthesia was maintained with $02 / \mathrm{N} 2 \mathrm{O}$ in a ratio of $50: 50$ and isoflurane $(0.6-1.0 \%)$ in both groups. Anesthesia was stopped at the end of surgery in all the patients. Results: Mean age of the patients was $40.49+11.47$ and $43.43+12.88$ years, $51.43 \%$ and $45.71 \%$ were male while $48.57 \%$ and $54.29 \%$ were females, Comparison of intubation conditions was recorded as $97.14 \%$ excellent and $2.86 \%$ good in patients received suxamethonium and $82.86 \%$ and $17.14 \%$ in Rocuronium Group had good conditions. Conclusion: It was found that Suxamethonium is significantly better when compared to Rocuronium for endotracheal intubation conditions in rapid sequence induction.

Key words: Endotracheal Intubating Conditions, Rapid Sequence Induction, Rocuronium, Suxamethonium.

Article Citation: Ahmad A, Aslam S, Tariq A, Firdous R, Ahmad H, Ahmed I. Comparison of rapid sequence induction intubation conditions with Suxamethonium verses Rocuronium. Professional Med J 2020; 27(4):759-764. DOI: 10.29309/TPMJ/2020.27.04.3667

\section{INTRODUCTION}

The most important clinical skill for an anesthesiologist and other providers who are involved in emergency ventilation is airway management. ${ }^{1}$ Full stomach patients presenting for emergency surgery or in Trauma room, the preferred method to secure airway is rapid sequence induction with cricoid pressure to avoid aspiration as it results in rapid unconsciousness (induction) and neuromuscular blockade (paralysis). $^{2}$

Steps of Rapid Sequence Induction include: Optimal positioning of the patient, Preoxygenation, Injection of an opioid and a Hypnotic, Injection of a fast-acting neuromuscular blocking agent (NMBA), Cricoid pressure, and Tracheal intubation. ${ }^{3}$
In order to have a rapid sequence induction a neuromuscular blocking agent should have following characteristics:1) Rapid onset and 2) Short duration of effect. ${ }^{4}$

Succinylcholine a depolarizing muscle relaxant is widely used drug in anesthesia for rapid sequence induction as it has the properties of very rapid onset and short duration, in addition to very good muscle relaxation. So, it provides the optimal conditions required for tracheal intubation. Adverse effects of Succinylcholine are mainly due to its depolarizing mechanism of action. Malignant hyperthermia and hyperkalaemia are potentially life threatening complications and a night mere for anesthetist. ${ }^{5}$

When we search for a non-depolarizing agent 
with rapid onset Rocuronium comes first. Among all the available non depolarizing agents it has rapid onset. The beauty of its use is it does not produce life threatening conditions like malignant hyperthermia and hyperkalemia. Contraindication to Rocuronium is the one which is same for all other non-depolarizing drugs that is patient allergic to the agent. So, this drug is regarded as an attractive alternative to Succinylcholine. ${ }^{6}$

As Rocuronium has faster onset of action among all available non depolarizing neuromuscular blockers, it produces comparable Intubating conditions to that of Succinylcholine. ${ }^{7}$ In a study when Intubating conditions were compared between Succinylcholine and Rocuronium, each variable of the intubating conditions was graded on four point scale (0-3) and given a score. Total 60 patients were included in study (30 in each group). In group A, where Suxamethonium was used, resulted in excellent intubating conditions. In group B, where Rocuronium was used, 25 patients showed excellent intubating conditions and 5 patients showed good intubating conditions. $^{8}$

It has been observed that Rocuronium has a better safety profile as compared to Suxamethonium. But in general practice Suxamethonium is more commonly used drug. We have done this study so that recommendations can be provided that among these two which agent provides better intubation conditions in rapid sequence induction.

\section{MATERIAL AND METHODS}

This study was done at allied hospital faisalabad from 2015-2016. In this study data was collected from 70 randomised patients ${ }^{8}$. All the patients were randomly divided into 2 groups by using computer generated random number table. Inclusion criteria were Patients undergoing emergency surgery, ASA grade I, ASA grade II, On airway assessment Mallampati class I (Soft palate, uvula, fauces, pillars visible) and Mallampati class II (Soft palate, uvula, fauces visible.) Age range from 12-60 years for both genders.

Exclusion criteria were Patients with previous history of allergy to Suxamethonium or Rocuronium, History of malignant hyperthermia in first degree relatives, Hyperkalemia ( $\mathrm{K}>$ $5.5 \mathrm{mEq} / \mathrm{L})$.

Bothgroupswereinduced with thiopentonesodium $5 \mathrm{mg} / \mathrm{kg}$, analgesia was given with nalbuphine $0.1 \mathrm{mg} / \mathrm{kg}$. Group A was given Suxamethonium in a dose of $1 \mathrm{mg} / \mathrm{kg}$ after induction agent. Group B received $0.6 \mathrm{mg} / \mathrm{kg}$ Rocuronium after induction. Intubation was performed after $60 \mathrm{sec}$ in both groups with cricoids pressure. Anesthesia was maintained with $02 / \mathrm{N} 2 \mathrm{O}$ in a ratio of $50 \%: 50 \%$ and isoflurane (0.6-1.0\%) in both groups. Data was collected using standardized performa and information comprised of age, gender, address, intubation induction score which was graded as excellent, good, depending upon ease of intubation according to clinical experience.

Intubating conditions were assessed using following scoring system. ${ }^{8}$

The numerical intubation score was obtained by summing up the scores assigned to the factors: laryngoscopy, vocal cords, and response to intubation. The maximum score is thus 9 , while the minimum score is 0 .

The qualitative intubation scores are defined as

\begin{tabular}{|c|c|c|c|c|}
\hline & Score 3 & Score 2 & Score1 \\
\hline $\begin{array}{c}\text { Jaw relaxation } \\
\text { (Measured clinically) }\end{array}$ & Poor Not Opening & $\begin{array}{c}\text { Minimal Some opening } \\
\text { with great restriction }\end{array}$ & $\begin{array}{c}\text { Moderate Half pening } \\
\text { with restriction }\end{array}$ & $\begin{array}{c}\text { Good Opening } \\
\text { without Restriction }\end{array}$ \\
\hline Vocal cords Movement & Open & Moving & Closing \\
\hline Intubation response & None & $\begin{array}{c}\text { Slight diaphragmatic } \\
\text { movement }\end{array}$ & Mild coughing & Severe oughing or \\
bucking
\end{tabular}


follows: 8

\begin{tabular}{|l|c|}
\hline \multicolumn{1}{|c|}{ Intubating Conditions } & Score \\
\hline Excellent & $8-9$ \\
\hline Good & $6-7$ \\
\hline Fair & $3-5$ \\
\hline Poor & $0-2$ \\
\hline
\end{tabular}

\section{RESULTS}

We selected 70 patients who were randomly divided into two groups meeting inclusion/ exclusion criteria to find frequency of endotracheal Intubating conditions in rapid sequence induction using Suxamethonium and Rocuronium.

Age distribution shows that $62.86 \%$ in and $54.29 \%$ were between $12-40$ years of age while $3.14 \%$ and $45.71 \%$ were between $41-60$ years of age in both Groups respectively, mean $+\mathrm{sd}$ was calculated as $40.49+11.47$ and $43.43+12.88$ years respectively. (See Figure-1)

Frequency of successful intubation among two groups according to Gender shows that $51.43 \%$ and $45.71 \%$ were male while $48.57 \%$ and $54.29 \%$ were females respectively. (See Figure- 2)

Successful intubation conditions among two groups were as $97.14 \%$ in Group-A and $82.86 \%$ in Group-B as excellent while $2.86 \%$ in Group-A and $17.14 \%$ in Group-B had good condition, $p$ value was calculated as 0.04 showing a significant difference. (Table-I)

Effect modifiers like age, gender ASA, were controlled by stratification. Post stratification chi-square test was applied. P-value $<0.05$ was taken as significant. (Table-II-IV)

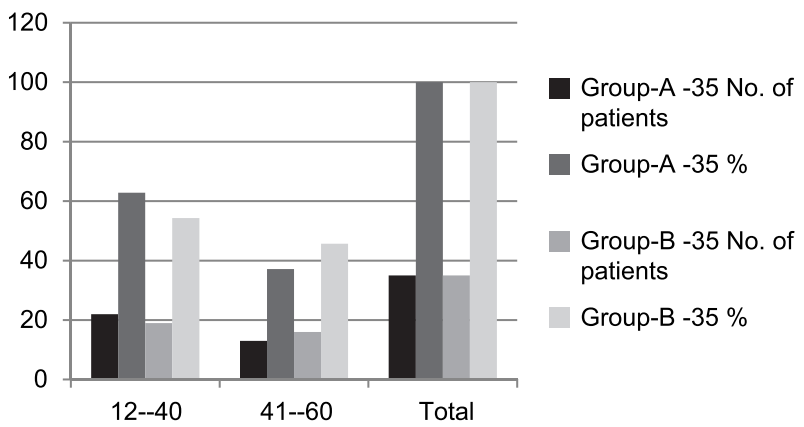

Figure-1. Age distribution.

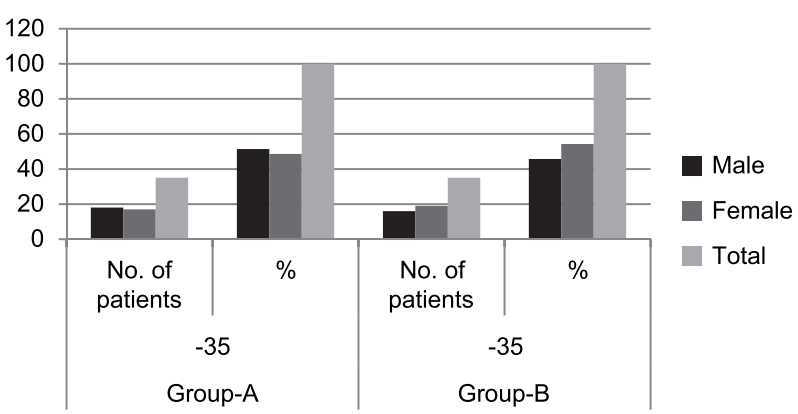

Figure-2. Gender distribution.

\begin{tabular}{|l|c|c|c|c|}
\hline & \multicolumn{2}{|c|}{$\begin{array}{c}\text { Group-A } \\
\text { Intubation }\end{array}$} & \multicolumn{2}{|c|}{$\begin{array}{c}\text { Group-B } \\
\text { (35) }\end{array}$} \\
\hline Conditions & $\begin{array}{c}\text { No. of } \\
\text { Patients }\end{array}$ & $\%$ & $\begin{array}{c}\text { No. of } \\
\text { Patients }\end{array}$ & $\%$ \\
\hline Excellent & 34 & 97.14 & 29 & 82.86 \\
\hline Good & 1 & 2.86 & 6 & 17.14 \\
\hline Total & 35 & 100 & 35 & 100 \\
\hline
\end{tabular}

Table-I. Comparison of intubation conditions (70). $P$ value $=0.04$

AGE: $12-40$

\begin{tabular}{|c|c|c|c|}
\hline \multirow{2}{*}{ Group } & \multicolumn{2}{|c|}{ Intubation Condition } & P-Value \\
\hline & Excellent & Good & \multirow{3}{*}{0.46} \\
\hline A & 21 & 1 & \\
\hline B & 17 & 2 & \\
\hline
\end{tabular}

AGE: 41-60

\begin{tabular}{|l|c|c|c|}
\hline \multirow{2}{*}{ Group } & \multicolumn{2}{c|}{$\begin{array}{c}\text { Excellent Intubation } \\
\text { Condition }\end{array}$} & P-Value \\
\cline { 2 - 3 } & Excellent & Good & \\
\hline A & 13 & 0 & 0.05 \\
\hline B & 12 & 4 & \\
\hline Table-III. Stratification for intubation conditions with \\
regards to gender.
\end{tabular}

Male

\begin{tabular}{|l|c|c|c|}
\hline \multirow{2}{*}{ Group } & \multicolumn{2}{|c|}{ Intubation Condition } & P-Value \\
\cline { 2 - 3 } & Excellent & Good & \\
\hline A & 17 & 1 & 0.47 \\
\hline B & 14 & 2 & \\
\hline
\end{tabular}


Female

\begin{tabular}{|l|c|c|c|}
\hline \multirow{2}{*}{ Group } & \multicolumn{2}{|c|}{ Intubation Condition } & P-Value \\
\cline { 2 - 3 } & Excellent & Good & \\
\hline A & 17 & 0 & 0.04 \\
\hline B & 15 & 4 & \\
\hline
\end{tabular}

Table-IV. Stratification for intubation conditions with regards to ASA.

ASA-I

\begin{tabular}{|c|c|c|c|}
\hline \multirow{2}{*}{ Group } & \multicolumn{2}{|c|}{ Intubation condition } & P-Value \\
\cline { 2 - 3 } & Excellent & Good & \\
\hline A & 21 & 1 & 0.49 \\
\hline B & 18 & 2 & \\
\hline
\end{tabular}

ASA-II

\begin{tabular}{|c|c|c|c|}
\hline \multirow{2}{*}{ Group } & \multicolumn{2}{|c|}{ Intubation condition } & P-Value \\
\cline { 2 - 3 } & Excellent & Good & \\
\hline A & 13 & 0 & 0.043 \\
\hline B & 11 & 4 & \\
\hline
\end{tabular}

\section{DISCUSSION}

Endotracheal intubation with rapid sequence induction (RSI) is required in patients who are considered full stomach or in anticipated difficult airway. ${ }^{9}$ Stept and Safar described Rapid sequence induction intubation first as having 15 steps to control airway in full stomach patients. Today it is used in anesthesia practice to rapidly gain airway control. ${ }^{10}$ Succinylcholine is, the only depolarizing agent available in anesthetic practice to provide good conditions for rapid sequence induction. ${ }^{11}$ Serious and dreadful problems which can occur with Succinylcholine like malignant hyperthermia, and hyperkalemia raised the need to find out other drugs for rapid sequence induction. So, other drugs have also been tried, all of them being non depolarizing agents showing different limitations. Rocuronium having rapid onset amongst them is considered a good agent. ${ }^{12}$ It has also been observed that Rocuronium is comparatively safe drug for rapid sequence induction. But in general practice Suxamethonium is more commonly used drug. However, we planned to compare these two drugs so that recommendations can be provided that which one of the two agents provide better conditiions in rapid sequence induction.
In our study, mean age was calculated as $40.49+11.47$ and $43.43+12.88$ years, $51.43 \%(18)$ and $45.71 \%(16)$ were male while $48.57 \%(17)$ and $54.29 \%(19)$ were females in both Groups respectively, mean Mallampati score in both groups was as $8.34+1.49$ in Group-A and $8.09+1.57$ in Group-B. Comparison of intubation conditions was recorded as $97.14 \%$ (34) and $82.86 \%$ (29) as excellent while $2.86 \%$ (1) and $17.14 \%$ (6) had good conditions in both Groups respectively. $P$ value was 0.04 which is significant.

In a study where intubating conditions were compared between Succinylcholine and Rocuronium, each variable of the intubating conditions was graded on four point scale (03) and given a score. Total 60 patients were included in study (30 in each group). In group $A$, where Suxamethonium was used, all 30 patients showed excellent intubating conditions. In group $B$, where Rocuronium was used, 25 patients showed excellent intubating conditions and 5 patients showed good intubating conditions8. These findings are in agreement with our study.

Tran DTT and others ${ }^{13}$ have conducted a study to compare that which drug (Rocuronium or Succinylcholine) provides excellent conditions for rapid sequence induction intubation in patients of all ages for elective and emergency situations and found that Rocuronium is less effective than Succinylcholine for providing acceptable intubation conditions. So, they concluded not to use Rocuronium when succinylcholine can be used and duration of intubation is expected to be shorter.

Sluga $\mathrm{M}$ and others ${ }^{14}$ when conducted a study over the succinylcholine and rocuronium in emergency intubations, they found that succinyl choline proves to provide better muscle relaxation for intubation.

Another study done by Jeffrey $J$ Perry and colleagues $^{15}$ found that Succinylcholine creates superior intubation conditions to Rocuronium when comparing both excellent and acceptable intubating conditions. 
Successful rapid sequence intubation depends upon many factors, including induction agent, choice of neuromuscular blocking agent, and patient positioning. ${ }^{16}$ Variations in induction agent should remain the choice of anesthetist according to the individual patient conditions. ${ }^{17}$ Succinylcholine remains the preffered drug because of rapid onset and short duration compared to slower onset and less satisfying intubation conditions with Rocuronium. . $18,19,20^{2}$

\section{CONCLUSION}

We concluded that Suxamethonium is significantly better when compared to Rocuronium for endotracheal intubation conditions in rapid sequence induction as $97.14 \%$ patients In group A had excellent intubation conditions and $2.86 \%$ had good conditions. No one had poor conditions for intubation in group A. $82.86 \%$ in group B had excellent conditions and $17.14 \%$ had well. The difference is significant in favor of suxamethonium.

\section{Copyright $\odot 25$ Aug, 2019.}

\section{REFERENCES}

1. Stewart JC, Bhananker S, Ramaiah R. Rapid-sequence intubation and cricoid pressure. Int J Crit IIIn Inj Sci. 2014; 4:42-49.

2. Mayglothling J, Duane T, Gibbs M, McCunn M, Legome E, Eastman A, Whelan J, Shah K. Emergency tracheal Intubation immediately following traumatic injury: An Eastern Association for the Surgery of Trauma practice management guideline. J Trauma Acute Care Surg. 2012; 73.

3. Sørensen MK, Bretlau C, Ga"tke MR, Sørensen AM, Rasmussen LS. Rapid sequence induction and intubation with Rocuronium-sugammadex compared with succinylcholine: A randomized trial. BJA; 2012; 1-8.

4. Luxen j, Trentzsch H, Urban B. Rocuronium und Sugammadex in der Notfallmedizin. Wiener klinisches Magazin, 2014; 17; 3,44-49.

5. Farhat K, Waheed A, Pasha AK, Tariq M. Effects of Rocuronium pretreatment on muscle enzyme levels following Succinylcholine. Pak J Pharm Sci. 2013; 26:939-42.
6. Marsch SC, Steiner L, Bucher E, Pargger H, Schumann M, Aebi T, Hunziker PR, Siegemund M. Succinylcholine versus Rocuronium for rapid sequence intubation in intensive care: A prospective, randomized controlled trial. Crit Care. 2011; 15:R199.

7. Rao MH, Venkatraman A, Malleswari R. Comparison of intubating conditions between Rocuronium with priming and without priming: Randomized and double-blind study. Indian J Anaesth. 2011;55:494-

8. Belekar VR, Khamankar S. Rocuronium for Tracheal Intubation in Patients Undergoing Emergency Surgery. IJPR; 2013; 3:18-22.

9. Frakes MA. Rapid sequence induction medications: An update. Journal of Emergency Nursing. 2003 Dec 1; 29(6):533-40.

10. Wang HE, Davis DP, Wayne MA, Delbridge T. Prehospital rapid-sequence intubation-what does the evidence show? Prehospital Emergency Care. 2004 Jan 1; 8(4):366-77.

11. Yazbeck MF, Finkelstein J, Dellinger RP. Rapid sequence intubation: Overview and myths versus facts. In Annual Update in Intensive Care and Emergency Medicine 20112011 (pp. 131-143). Springer, Berlin, Heidelberg.

12. Magorian T, Flannery KB, Miller RD. Comparison of Rocuronium, Succinylcholine, and vecuronium for rapid-sequence induction of anesthesia in adult patients. Anesthesiology. 1993 Nov; 79(5):913-8.

13. Tran DTT, Newton EK, Mount VAH, Lee JS, Wells GA, Perry JJ. Rocuronium versus Succinylcholine for rapid sequence induction intubation. Cochrane database of systematic Reviews 2015, Issue 10. Art. No.: CD002788. DOI:10.1002/14651858.CD002788. pub3.(83)

14. Sluga M, Ummenhofer W, Studer W, Siegemund M, Marsch SC. Rocuronium versus Succinylcholine for rapid sequence induction of anesthesia and endotracheal intubation: A prospective, randomized trial in emergent cases. Anesth Analg. 2005; 101(5):1356-61.

15. Perry JJ, Lee JS, Sillberg VAH, Wells GA. Rocuronium versus Succinylcholine for rapid sequence induction intubation. Cochrane Database of Systematic Reviews 2008, Issue 2. Art. No.: CD002788. DOI:10.1002/14651858.CD002788.pub2.

16. El-Orbany M, Connolly LA. Rapid sequence induction and intubation: Current controversy. Anesthesia \& Analgesia. 2010 May 1; 110(5):1318-25. 
17. Koerber JP, Roberts GE, Whitaker R, Thorpe CM. Variation in rapid sequence induction techniques: current practice in Wales. Anaesthesia. 2009 Jan; 64(1):54-9.

18. Zelicof-Paul A, Smith-Lockridge A, Schnadower D, Tyler $\mathrm{S}$, Levin S, Roskind C, Dayan P. Controversies in rapid sequence intubation in children. Current opinion in pediatrics. 2005 Jun 1; 17(3):355-62.
19. Cheng CA, Aun CS, Gin T. Comparison of Rocuronium and Suxamethonium for rapid tracheal intubation in children. Pediatric Anesthesia. 2002 Feb; 12(2):140-5.

20. Sajayan A, Wicker J, Ungureanu N, Mendonca C, Kimani PK. Current practice of rapid sequence induction of anaesthesia in the UK-a national survey. BJA: British Journal of Anaesthesia. 2016 Feb 24; 117(suppl_1):i69-74.

\begin{tabular}{|c|c|c|c|}
\hline \multicolumn{4}{|c|}{ AUTHORSHIP AND CONTRIBUTION DECLARATION } \\
\hline Sr. \# & Author(s) Full Name & Contribution to the paper & Author(s) Signature \\
\hline 1 & Aisha Ahmad & $\begin{array}{l}\text { All authors contributed equally } \\
\text { for this study. }\end{array}$ & \\
\hline 2 & Samina Aslam & & Kabana \\
\hline 3 & Amna Tariq & & \\
\hline 4 & Robina Firdous & & \\
\hline 5 & Humaira Ahmad & & \\
\hline 6 & ljaz Ahmed & & \\
\hline
\end{tabular}

